\title{
PERCEPTION OF CORPORATE SOCIAL RESPONSIBILITY- A COMPARISON STUDY BETWEEN POLISH AND SLOVAK CONSUMERS
}

\author{
Renata Matysik-Pejas ${ }^{1 ;}$ Dr. Ing.; Elena Horska², prof. Dr. Ing. \\ ${ }^{1}$ Agricultural University in Krakow, Poland; ${ }^{2}$ Slovak University of Agriculture in Nitra, Slovakia
}

\begin{abstract}
Corporate Social Responsibility is a modern business philosophy, according to which the organization has to pursue their economic goals, and at the same time be responsible for the impact on the environment and quality of society life. One of the direct interaction groups of enterprises, representing an increasingly important area of CSR, are consumers. Achieving measurable effects of CSR activities is possible under condition that consumers are aware of them, have positive perception of the specific messages and that this raise the credibility of the organization in their opinion. The main goal of the study was to determine which areas of Corporate Social Responsibility implemented by food producers are perceived as the most important by consumers from Poland and Slovakia. The primary information used for the analyses and inference was derived from two independent consumer studies conducted during the period from November 2017 to January 2018 in Slovakia (Nitra Region) and in Poland (Malopolska Province). PAPI method was used for collection of the empirical material. 279 respondents participated in the study conducted in Slovakia and 272 respondents in Poland. For both consumers from Poland and Slovakia relationships with employees are the most important area of CSR. Developing good relationships with this stakeholder group should include meeting obligations, honesty, dialogue and cooperation, but also increasing employees' economic satisfaction. If a gap exists in meeting the employees' needs, it is impossible to build a high reputation of the enterprise in the area of social responsibility.
\end{abstract}

Key words: CSR, consumers, Poland, Slovakia.

JEL code: D19, L21, M14

\section{Introduction}

Increased interest in social responsibility, perceivable in recent years, results from many causes. They include: globalisation, progressing degradation of the natural environment, changing socio-cultural conditionings, a change of awareness of employees and the whole society and growing competition (Ratajczak, Woloszyn and Stawicka, 2012).

Corporate social responsibility (SCR) has its roots in ethical standards with have a character of extra-judicial instruments, supplementing the law and filling in the space between its regulations and so called principles of good coexistence (Demkow, Sulich, 2017). This aspect has been emphasized by Davis (1973), according to whom social responsibility starts where the influence of law ends. CSR concept also fits in a wider trend of sustainable development which is a philosophy of running economic activity according to the principle of combined economic, social and ecological aims and minimising the negative impact of the organisation on the environment, at simultaneous striving to maintain durability and harmony of the world development (Witek-Crabb, 2016). CSR is classified to non-material resources, which create the value of business and influence the building of competitive advantage (Bobola, 2014).

CSR is defined as an idea, owing to which at the stage of building their strategies, enterprises voluntarily and with full responsibility consider the social interests and environmental protection (Balaban et al., 2012; Baumgartner, 2014), but also build permanent positive relations with various stakeholder groups, such as employees, customers, business partners, local communities or local and state administration (Oeberseder et al., 2013; Gangone, Ganescu, 2014; Wu, Lin, 2014).

Social awareness of businesses operations in the area of CSR seems low (Bhattacharya and Sen, 2004). Many consumers lack information whether a given firm gets involved in voluntary 
service, or in activities for the society or environment. Therefore, announcing CSR initiatives to consumers is very important. One of the key aspects of good practices in the area of CSR are efficient and clear communication channels. Efficient two-way communication of a firm with the outer environment serves to increase its input for improving life standards of a given community, because it allows to determine the issues and potential problems which the business should face and, after realising some defined initiatives, it should disseminate the results of undertaken activities among the interested parties (Gluszek, 2013). Owing to communication of initiatives and social involvement an enterprise stimulates positive attitudes towards itself, minimises losses of reputation and protects against negative outcomes of possible crisis situations (Fryzel, 2014). Achieving measurable effects of CSR activities is possible under condition that consumers are aware of them, have positive perception of the specific messages and that this raise the credibility of the organization in their opinion.

The aim of the study was to determine which areas of Corporate Social Responsibility implemented by food producers are perceived as the most important by consumers from Poland and Slovakia.

In order to achieve the aim, the following research tasks were established:

- to determine the importance for consumers of selected ways of engaging of food producers in CSR,

- to applicate an analytical method allowing to group assessed ways of engaging food producers in CSR in order to detect hidden interrelations between them,

- to establish a hierarchy of highlighted CSR areas for consumers from Poland and Slovakia.

\section{Data and methodology}

The primary information used for the analyses and inference was derived from two independent consumer studies conducted during the period from November 2017 to January 2018 in Slovakia (Nitra Region) and in Poland (Malopolska Province). PAPI method was used for accumulation of the empirical material. The same questionnaire (in an appropriate language version) was used for both studies. 279 respondents participated in the study conducted in Slovakia (RSK) and 272 respondents (RPL) in Poland. The selection of respondents for the sample was non-randomised.

Women prevailed in both respondent groups from Slovakia and Poland, constituting respectively $63.7 \%$ and $54.4 \%$. Young persons, aged below 25 were dominant in the age structure of the analysed groups, their proportion in RSK group was $43.9 \%$ and in RLP group $37.5 \%$. Persons living in rural areas made up a majority (56.1) of the respondents in Slovakia, whereas city dwellers prevailed among the respondents in Poland (52.9\%).

Analysis of the empirical material was conducted using factor analysis. Factor analysis is a group of exploratory methods and statistical procedures allowing to reduce a big number of studied variables to a considerably smaller number of mutually independent (non-correlated) factors (Fabrigar et al., 1999). The identified factors represent so called hidden variables, which are not directly observable. They also retain a part of information contained in the primary variables. Principle components method was applied in the conducted analysis for the factors identification. The factors rotation was conducted using varimax method, which allows for the simplification of the factors interpretation. Several solutions with a lower or higher number of factors (taking into consideration both Kaiser test and scree test) were tested during the analysis and subsequently a solution with three factors was selected, which is the best from the point of view of the obtained 
results and their possible interpretation (Williams et al., 2010). Variables with the highest loadings were isolated within the factors, which fulfilled the condition that the minimum correlation level is 0.5 (Brown, 2009).

\section{Research results and discussion}

The scope of activities, which enterprises may undertake while realising the assumptions of Corporate Social Responsibility for individual stakeholder groups, the natural environment, education or social involvement is very wide. The presented studies analysed 23 potential components of such activity with reference to food enterprises. The respondents assessed them on a five-point scale, where 1 denoted little importance, whereas 5 very big importance. Application of factor analysis allowed to reduce the primary set of 23 variables for each investigated respondent group to three factors, which explain respectively $53.4 \%$ of total variability in case of studies conducted on the respondent group from Poland (RPL) and $54.5 \%$ for the studies conducted among the respondents from Slovakia (RSK).

Eigenvalues of isolated factors for respondent group from Poland (RPL) and respondent group from Slovakia (RSK)

\begin{tabular}{|l|c|c|c|c|c|c|}
\hline & \multicolumn{3}{|c|}{ RPL } & \multicolumn{3}{c|}{ RSK } \\
\hline Factors & F1PL & F2PL & F3PL & F1SK & F2SK & F3SK \\
\hline Eigenvalue of factor & 8.23 & 2.43 & 1.63 & 6.95 & 2.80 & 2.78 \\
\hline $\begin{array}{l}\text { Percentage of the total of } \\
\text { eigenvalues (variance) }\end{array}$ & 35.77 & 10.58 & 7.07 & 30.22 & 12.16 & 12.08 \\
\hline Cumulative eigenvalue & 8.23 & 10.66 & 12.29 & 6.95 & 9.75 & 12.52 \\
\hline $\begin{array}{l}\text { Cumulative \% of } \\
\text { eigenvalues }\end{array}$ & 35.77 & 46.35 & 53.42 & 30.22 & 42.37 & 54.45 \\
\hline
\end{tabular}

Source: author's calculations based on own research

Both in case of studies conducted in RPL and SRK group, the first isolated CSR factor concerns "the enterprise relations with its employees". Results of analysis obtained for RPL allow for an observation, that this factor (F1PL) whose eigenvalue was 8.23 explained $35.85 \%$ of the total variability of the investigated phenomenon. On the other hand, the eigenvalue of the first factor (F1SK) for RSK had a lower value, i.e. 6.95 and explained $30.2 \%$ of the total variability of the phenomenon. 
Results of factor analysis for respondent group from Poland (RPL) and respondent group from Slovakia (RSK)

\begin{tabular}{|c|c|c|c|c|c|c|}
\hline \multirow[b]{2}{*}{ Variables } & \multicolumn{3}{|c|}{ RPL } & \multicolumn{3}{|c|}{ RSK } \\
\hline & $\begin{array}{l}\text { Factor } \\
\text { F1PL }\end{array}$ & $\begin{array}{l}\text { Factor } \\
\text { F2PL }\end{array}$ & $\begin{array}{l}\text { Factor } \\
\text { F3PL }\end{array}$ & $\begin{array}{l}\text { Factor } \\
\text { F1SK }\end{array}$ & $\begin{array}{l}\text { Factor } \\
\text { F2SK }\end{array}$ & $\begin{array}{l}\text { Factor } \\
\text { F3SK }\end{array}$ \\
\hline Conducting business ethically & 0.322 & 0.194 & 0.428 & 0.093 & 0.316 & 0.375 \\
\hline Avoiding dishonest competition & 0.139 & 0.244 & 0.528 & 0.103 & 0.536 & 0.200 \\
\hline Offering safe products & 0.252 & -0.049 & 0.771 & 0.220 & 0.807 & -0.044 \\
\hline Offering honest product prices & 0.389 & 0.009 & 0.658 & 0.194 & 0.778 & 0.040 \\
\hline $\begin{array}{l}\text { Providing clear information about the } \\
\text { business }\end{array}$ & 0.134 & 0.505 & 0.460 & 0.088 & 0.807 & 0.043 \\
\hline $\begin{array}{l}\text { Providing clear information about } \\
\text { products }\end{array}$ & 0.160 & 0.178 & 0.738 & 0.181 & 0.783 & 0.077 \\
\hline Running a website & 0.096 & 0.564 & -0.027 & 0.148 & 0.230 & 0.179 \\
\hline $\begin{array}{l}\text { Running e.g. telephone consumer } \\
\text { service }\end{array}$ & -0.050 & 0.648 & -0.010 & 0.100 & 0.681 & 0.113 \\
\hline Compliance with labour law & 0.536 & 0.135 & 0.324 & 0.626 & 0.419 & -0.077 \\
\hline Offering decent wages & 0.716 & 0.101 & 0.402 & 0.747 & 0.220 & -0.008 \\
\hline $\begin{array}{l}\text { Creating friendly atmosphere in the } \\
\text { workplace }\end{array}$ & 0.720 & 0.203 & 0.336 & 0.743 & 0.131 & 0.140 \\
\hline Equal treatment of employees & 0.782 & 0.153 & 0.212 & 0.858 & 0.164 & 0.067 \\
\hline Creating stabile working conditions & 0.718 & 0.002 & 0.280 & 0.835 & 0.112 & -0.030 \\
\hline Training and development of employees & 0.657 & 0.148 & 0.231 & 0.751 & -0.035 & 0.229 \\
\hline Promotion opportunities & 0.729 & 0.217 & 0.118 & 0.816 & 0.162 & 0.125 \\
\hline Supporting employees' families & 0.713 & 0.378 & -0.090 & 0.638 & 0.200 & 0.180 \\
\hline $\begin{array}{l}\text { Compliance with environmental } \\
\text { legislation }\end{array}$ & 0.319 & 0.647 & 0.063 & 0.323 & 0.009 & 0.667 \\
\hline Reduction of waste volume & 0.212 & 0.688 & 0.341 & 0.289 & -0.118 & 0.699 \\
\hline $\begin{array}{l}\text { Reduced energy and water } \\
\text { consumption }\end{array}$ & 0.169 & 0.674 & 0.367 & 0.241 & -0.025 & 0.762 \\
\hline Charity activities & 0.486 & 0.537 & -0.141 & -0.183 & 0.232 & 0.711 \\
\hline Social projects & 0.186 & 0.681 & 0.044 & -0.076 & 0.146 & 0.689 \\
\hline Promotion of art and education & 0.391 & 0.596 & -0.150 & 0.010 & 0.122 & 0.606 \\
\hline Creating new jobs & 0.443 & 0.359 & 0.210 & 0.274 & 0.517 & 0.194 \\
\hline
\end{tabular}

Source: author's calculations based on own research

For both investigated groups RPL and RSK the same eight variables were correlated with the first factor. The studies indicate that the element with the highest factor loading, both in RPL and RSK group turned out to be the issue of equal treatment of the employees; however, the value for RSK group was higher (0.858) than for RPL group (0.782). In RSK group factor loadings of the other variables had values from 0.835 for the "creating stabile working conditions" variable to 0.626 for "compliance with labour law" variable. Values of the other loadings in RPL group for this factor fluctuated from 0.729 for "promotion opportunities" variable to 0.539 for the same variable as in RSK group.

In case of the second and third isolated factors no such similarities occurred for groups RPL and RSK and these were formed (with only some exceptions) by different variables.

In RSK group, the second identified factor (F2SK) with eigenvalue 2.80 explained $12.2 \%$ of total variability of the set. It was formed by seven variables, of which the character of six corresponded to the area relations with consumers. The "offering safe products" variable obtained 
the highest value of the factor loading $(0.807)$, whereas "creating new jobs", which by its character differed from the others, received the lowest value (0.517).

In RPL group, the second factor (F2PL) had its eigenvalue on the level of 2.43 and represented $10.6 \%$ of variance of the set. The variables, which were correlated with it were diversified in their character, because three of them represented the area of environmental protection, three were connected with social area, whereas the other three represented relations with consumers. The highest value of factor loading characterised "reduction of waste volume" variable $(0.688)$, whereas the lowest "providing clear information about the enterprise" variable (0.505).

The eigenvalue of the third factor (F3SK) obtained for RSK group was 2.78 and in fact was identical as for the second factor. Thereby it also explained a similar value of the variance of the set $(12.08 \%)$. The factor was formed by seven variables connected with such areas of CSR as environmental and social issues. Among the individual variables, "reduced energy and water consumption" variable had the highest value of factor loading $(0.762)$, whereas the lowest was noted for "promotion of art and education" variable (0.606).

The third factor (F3PL) isolated for RPL group had the eigenvalue lower than for RSK group. In this case it was 1.63 and explained 5 pp less variances of the set than in case of RSK group. This factor constituted of four variables characterising the enterprise market relations, however the variable with the highest factor loading was "offering safe products" $(0.771)$, whereas the lowest factor loading was attached to "avoiding dishonest competition" (0.528).

Out of the 23 analysed variables, one "conducting business ethically" variable was not included in any of the three identified factors for both analysed groups. 
Characteristics of factors identified for respondent group from Poland (RPL) and respondent group from Slovakia (RSK)

\begin{tabular}{|c|c|c|c|}
\hline Factor & RPL & Factor & RSK \\
\hline \multirow[b]{2}{*}{$\begin{array}{l}\text { Factor } \\
\text { F1PL }\end{array}$} & Area: relations with employees & \multirow[b]{2}{*}{$\begin{array}{l}\text { Factor } \\
\text { F1SK }\end{array}$} & Area: relations with employees \\
\hline & $\begin{array}{l}\text { Equal treatment of employees } \\
\text { Promotion opportunities } \\
\text { Creating friendly atmosphere in the workplace } \\
\text { Creating stabile working conditions } \\
\text { Offering decent wages } \\
\text { Supporting employees' families } \\
\text { Training and development of employees } \\
\text { Compliance with labour law }\end{array}$ & & $\begin{array}{l}\text { Equal treatment of employees } \\
\text { Creating stabile working conditions } \\
\text { Promotion opportunities } \\
\text { Training and development of employees } \\
\text { Offering decent wages } \\
\text { Creating friendly atmosphere in the workplace } \\
\text { Supporting employees' families } \\
\text { Compliance with labour law }\end{array}$ \\
\hline \multirow[b]{2}{*}{$\begin{array}{l}\text { Factor } \\
\text { F2PL }\end{array}$} & Area: environmental-social relations & \multirow[b]{2}{*}{$\begin{array}{l}\text { Factor } \\
\text { F2SK }\end{array}$} & Area: relations with consumers \\
\hline & $\begin{array}{l}\text { Reduction of waste volume } \\
\text { Social projects } \\
\text { Reduced energy and water consumption } \\
\text { Running e.g. telephone consumer service } \\
\text { Compliance with environmental legislation } \\
\text { Promotion of art and education } \\
\text { Running a website } \\
\text { Charity activities } \\
\text { Providing clear information about the business }\end{array}$ & & $\begin{array}{l}\text { Offering safe products } \\
\text { Providing clear information about the business } \\
\text { Providing clear information about products } \\
\text { Offering honest product prices } \\
\text { Running e.g. telephone consumer service } \\
\text { Avoiding dishonest competition } \\
\text { Creating new jobs }\end{array}$ \\
\hline \multirow[b]{2}{*}{$\begin{array}{l}\text { Factor } \\
\text { F3PL }\end{array}$} & Area: relations with consumers & \multirow[b]{2}{*}{$\begin{array}{l}\text { Factor } \\
\text { F3SK }\end{array}$} & Area: environmental-social relations \\
\hline & $\begin{array}{l}\text { Offering safe products } \\
\text { Providing clear information about products } \\
\text { Offering honest product prices } \\
\text { Avoiding dishonest competition }\end{array}$ & & $\begin{array}{l}\text { Reduced energy and water consumption } \\
\text { Charity activities } \\
\text { Reduction of waste volume } \\
\text { Social projects } \\
\text { Compliance with environmental legislation } \\
\text { Promotion of art and education }\end{array}$ \\
\hline
\end{tabular}

Source: author's calculations based on own research

It has been confirmed in the literature that these days the society perceives positively the organisations, whose employees feel financially safe and are sure of their employment in the perspective of the succeeding years (Rok, 2004). Employees form an internal stakeholder group of each business, for which they are simultaneously the key resources determining its success of failure (Azim, 2016). The way in which the employees are treated, whether their rights are respected and on which principles the staff policy is based significantly influence the degree of employee integration with the enterprise, their emotional involvement in the assigned tasks, satisfaction from work and loyalty to the organisation (Gadomska-Lila, 2012; Lee et al., 2013; Suh, 2016). Application by the enterprise of clear and stabile principles of staff policy causes that the employees perceive their workplace positively, which owing to this fact becomes for them the source of safety and mental comfort (Bartkowiak, 2011). Relationships of this type have a direct influence on employee commitment to work, which means that they become legitimate members of the enterprise. One of important aspects of CSR is motivating employees. In this context promotion may be indicated as an important element of motivation connected with a change of an employee's position in the enterprise organisational structure. At the same time, it fulfils the need for appreciation and positive self-assessment, but also gives access to higher values and improving employee's living standards (Mazur, 2013). Another important aspect of the enterprise relationship with employees are trainings. Personal development of the employees takes place when their 
knowledge in the area necessary at the position they occupy is improved. Owing to trainings employees gain additional professional skills and their self-esteem, as well as the sense of belonging to the firm grow (Kalinowska, 2012).

Consumers constitute an external group of a business stakeholders. The area of relationships with consumers is a vast CSR category, among other comprising provision of clear information about the enterprise and its products and offering safe products for honest prices. Due to a specific character of food products, the enterprises in this branch are in the first place obliged to provide honest information for the consumers about their product composition and nutritional values. All the relevant data - the shelf life date and allergen content should be placed on the label. Enterprises must ensure food safety (Gardner, 1993), i.e. they must know the source of origin of the components they use, control the conditions in which the products are manufactured, but also commission independent and reliable quality tests. Food enterprises are forbidden to use genetic engineering to modify food products and conceal this fact from the customers. Food producers should not label their products by certificates misleading the consumers (Spoleczna odpowiedzialnosc..., 2015). Food producers should care about their reliability towards consumers; therefore, the enterprises implementing the principles of CSR in the area of market relations, have chances for advantageous image.

The natural environment is determined as a "mute stakeholder" because it does not call for its advantages but the negative consequences of its disregard in the business activities are perceptible by all (Zelazna-Blicharz, 2013). Separating the area of environment in the CSR concept emphasizes its importance in the enterprises activities. The state of the natural environment is one of the factors influencing the life quality of society. Responsibility of enterprises towards the natural environment is interpreted as a necessity for reducing energy and raw materials consumption and limiting emissions of harmful substances and waste from production processes. Minimisation of a negative impact of production on the environment are the key activities which the enterprises may conduct to face the environmental challenges (Mazurkiewicz and Grenna, 2003).

The area of CSR activity connected with the society is perceptible as implementing the society supporting programmes, caring about the improvement of society's living standards; voluntary activities and philanthropic activities. Charity and voluntary service counteract the egoism in social life and are a sign of respect towards the most needy.

\section{Conclusions}

1) Basing on the conducted factor analysis three factors were identified for each of the studied respondent groups, which together with a set of variables connected with them have influence on the consumer perception of the importance of CSR realised by food producers.

2) For both consumers from Poland and Slovakia relationships with employees are the most important area of CSR. Developing good relationships with this stakeholder group should include meeting obligations, honesty, dialogue and cooperation, but also increasing employees' economic satisfaction. If a gap exists in meeting the employees' needs, it is impossible to build a high reputation of the enterprise in the area of social responsibility.

3) The second identified factor for the respondents from Slovakia and the third one for the respondents from Poland constituted the CSR area concerning the relations with consumers. These relations are fundamental for the functioning of food producers, therefore they must run 
their businesses offering consumers safe products, honest prices and reliable marketing. It provides a basis for creating a positive image of the enterprise among consumers.

4) For the respondents from Poland the second distinct factor was connected with the area described as environmental-social relations. For the respondent group from Slovakia the same area constituted the third of the identified factors. The environmental and social aspects are also basic assumptions of CSR. Long-term and measurable social investments undertaken by enterprises improve their relations with stakeholders. On the other hand conducting operations accountable to the environment contributes to sustainable development, including health and wellbeing in society.

\section{Bibliography}

1. Azim, M.T. (2016). Corporate Social Responsibility and Employee Behavior: Mediating Role of Organizational Commitment. Revista brasileira de gestao de negocios. Vol.18 (60), pp: 207-225, doi: 10.7819/rbgn.v18i60.2319.

2. Balaban, O., Cicioglu, F., Okutan, E. (2012). A Survey Aimed at Role and Importance of Non-Governmental Organizations in the Corporate Social Responsibility (CSR). Procedia - Social and Behavioral Sciences. 58, 1174-1182, doi:10.1016/j.sbspro.2012.09.1099.

3. Bartkowiak, G. (2011). Dobrostan pracownikow, poziom „zdrowia organizacji” a ich zadowolenie z pracy $i$ zaangazowanie w osiaganie celow organizacji (Employees Well-Being, Job, Satisfaction, "Organizational Health" and Workers' Engagement in Organizational Goals). Prace Naukowe Uniwersytetu Ekonomicznego we Wroclawiu. No. 223, pp. 200-210.

4. Baumgartner, R. J. (2014). Managing Corporate Sustainability and CSR: A Conceptual Framework Combining Values, Strategies and Instruments Contributing to Sustainable Development. Corporate Social Responsibility and Environmental Management, 21(5), pp. 258-271, doi: 10.1002/csr.1336.

5. Bhattacharya, C. B., Sen, S. (2004). Doing Better at Doing Good: When, Why and How Consumers Respond to Corporate Social Initiatives. California Management Review 47 (Fall), pp. 9-25.

6. Bobola, A.M. (2014). Spoleczna odpowiedzialnosc biznesu jako zasob niematerialny ksztaltujacy przewage konkurencyjna przedsiebiorstw spozywczych (Corporate Social Responsibility as an Intangible Assets Shaping the Competitive Advantage of Food Companies). Roczniki Naukowe SERiA, XVI (3), pp. 36-42.

7. Brown, J.D. (2009). Choosing the Right Type of Rotation in PCA and EFA. JALT Testing \& Evaluation SIG Newsletter. 13 (3), pp. $20-25$.

8. Davis, K. (1973). The Case Against Business Assumption of Social Responsibilities, Academy of Management Journal, Vol.16.ń

9. Demkow, K., Sulich, A. (2017). Wybrane wyzwania zwiazane ze spoleczna odpowiedzialnoscia duzych i srednich podmiotow gospodarczych (Selected Challenges Related to Corporate Social Responsibility of Medium and Large Business Entities). Marketing i Rynek. No. 11, pp. 42-52.

10. Fabrigar, L.R., Wegene, r D.T., MacCallum, R.C., Strahan, E.J. (1999). Evaluating the Use of Exploratory Factor Analysis in Psychological Research. Psychological Methods. Vol. 4. Iss.: 3, pp. 272-299, doi: 10.1037/1082-989X.4.3.272

11. Fryzel, B. (2014). CSR i emocjonalnosc konsumenta - czy spolecznie wrazliwi konsumenci racjonalizuja swoje wybory ekonomiczne (CSR and Consumer's Emotionality. Do Socially Sensitive Consumers Rationalize their Economic Choices?). Studia Ekonomiczne. No. 180, pp. 88-98.

12. Gadomska-Lila. K (2012). Spoleczna odpowiedzialnosc biznesu wobec pracownikow (Corporate Social Responsibility Towards Employees). Management and Business Administration. Central Europe. 2 (115), pp. 41-52, doi: 10.7206/mba.ce.2084-3356.4.

13. Gangone, A.D., Ganescu, M.C . (2014). Corporate Social Responsibility in Emerging and Developing Economies in Central and Eastern Europe - a Measurement Model From the Stakeholder Theory Perspective. Economic Research - Ekonomska Istrazivanja. 27(1), pp. 539-558, doi: 10.1080/1331677X.2014.967535

14. Gardner, S. (1993). Consumers and Food Safety: a Food Industry Perspective. Retrieved: http://www.fao.org/docrep/V2890T/v2890t05.htm. Access: 30.01.2018.

15. Gluszek, E. (2013). Wykorzystywanie inicjatyw spolecznych w budowaniu atrybutow dobrej reputacji przedsiebiorstwa (Social Initiatives in Building Key Ingredients of Star-Quality Corporate Reputation). Prace Naukowe Uniwersytetu Ekonomicznego we Wroclawiu. No.288, pp. 22-36.

16. Kalinowska A. (2012). Wartosc dla pracownikow w koncepcji CSR (Value for Employees in CSR). Zeszyty Naukowe Uniwersytetu Szczecinskiego, Finanse, Rynki Finansowe, Ubezpieczenia. No. 55, pp. 327-344.

17. Lee, E.M., Park, S., Lee, H. (2013). Employee Perception of CSR Activities: Its Antecedents and Consequences. Journal of Business Research. No. 66, pp. 1716-1724, doi: 10.1016/j.jbusres.2012.11.008.

18. Mazur, B. (2013). Motywowanie pracownikow jako istotny element zarzadzania organizacja (Motivating Employees as a Key Partof Organization Management). Nauki Spoleczne, No. 2(8), pp. 156-182.

19. Mazurkiewicz, P. , Grenna, L. (2003). Corporate Social Responsibility and Multi-Stakeholder Dialogue. Towards Environmental Behavioral Change. Discussion Paper. May 2003, World Bank. 
20. Oeberseder, M., Schlegelmilch, B., Murphy, P. E. (2013). CSR Practices and Consumer Perceptions. Journal of Business Research. 66(10), 1839-1851, doi: 10.1016/j.jbusres.2013.02.005.

21. Rok, B. (2004). Odpowiedzialny biznes w nieodpowiedzialnym swiecie (Responsible Business in an Irresponsible World), Akademia Rozwoju Filantropii w Polsce - Forum Odpowiedzialnego Biznesu, Warszawa, p. 37.

22. Spoleczna odpowiedzialnosc biznesu w polskich realiach. Teoria i praktyka (Corporate Social Responsibility in Polish Realities. Theory and Practice). 2015. Retrieved: http:// http://www.centrumcsr.pl/wpcontent/uploads/2015/12/Spo \%C5 \%82eczna-odpowiedzialno \%C5 \%9B \%C4 \%87-biznesu-w-polskichrealiach.-Teoria-a-praktyka.pdf. Access: 30.01.2018.

23. Suh, Y. J. (2016). The role of relational social capital and communication in the relationship between CSR and employee attitudes: a multilevel analysis. Journal of Leadership \& Organizational Studies. 23, pp. 410-423, doi: 10.1177/1548051816637564.

24. Williams, B., Brown, T., Onsman, A. (2010). Exploratory Factor Analysis: A Five-Step Guide for Novices. Australasian Journal of Paramedicine. 8(3), pp. 1-13.

25. Witek-Crabb, A. (2016). Ewolucyjne modele CSR - przeglad koncepcji rozwoju spolecznej odpowiedzialnosci biznesu (Evolutionary Stage Models of Corporate Social Responsibility - Theory Review). Prace Naukowe Uniwersytetu Ekonomicznego we Wroclawiu, No. 444, pp. 541-558.

26. Woloszyn, J., Stawicka, E., Ratajczak, M. (2012). Spoleczna odpowiedzialnosc malych i srednich przedsiebiorstw agrobiznesu z obszarow wiejskich (Social Responsibility of Small and Medium-Sized Agribusiness Enterprises from Rural Areas). SGGW, Warszawa, 88 p.

27. Wu, S.-I., Lin, H.-F. (2014). The Correlation of CSR and Consumer Behavior: A Study of Convenience Store. International Journal of Marketing Studies. 6(6), pp. 66-80, doi:10.5539/ijms.v6n6p66.

28. Zelazna-Blicharz, A. (2013). Spoleczna odpowiedzialnosc w procesie gospodarowania a zrownowazona produkcja $i$ konsumpcja (Social Responsibility in the Management Process and Sustainable Production and Consumption). Politechnika Lubelska, Lublin, $221 \mathrm{p}$. 